\title{
Effect of Different Types of Tillage and Sowing Methods on Growing and Yield of Chickpea Crop
}

\author{
Yogesh Ku. Kosariya ${ }^{1 *}$, A.K. Verma ${ }^{2}$ Shubham $^{2}$ and Sangeeta $^{3}$ \\ ${ }^{1}$ Department of Farm Machinery and Power Engineering, Raipur (C.G. ), 492012, India \\ ${ }^{2}$ Faculty of Agricultural Engineering, Raipur (C.G.), 492012, India \\ ${ }^{3}$ GKV, Raipur (C.G.), 492012, India \\ *Corresponding author
}

\section{Keywords}

Conventional seed cum fertilizer drill, Happy seeder, Conservation agriculture, Zero tillage

Article Info

Accepted:

20 January 2019

Available Online:

10 February 2019

\section{A B S T R A C T}

Evaluation of different chickpea sowing technologies under paddy residue conditions was conducted in a harvested paddy field. Field of paddy was harvested with combine. Chickpea variety (JG-130) was sown with different farm machines in four treatments viz., $\mathrm{T}_{1}$ : Happy seeder, $\mathrm{T}_{2}$ : Zero till seed cum fertilizer drill, $\mathrm{T}_{3}$ : Conventional seed cum fertilizer drill and $\mathrm{T}_{4}$ : Raised bed seed cum fertilizer drill in harvested R-1 variety of paddy fields. In $T_{1}$, all the paddy straw was remained in the field itself and spreaded uniformly. While in $T_{2}, T_{3}$ and $T_{4}$, maximum loose paddy straw was removed manually for better operation of the machines. The maximum total yield of chickpea grain was obtained in treatment $\mathrm{T}_{1}$ (happy seeder, $1137.8 \mathrm{~kg} / \mathrm{ha}$ ) followed by treatment $\mathrm{T}_{4}$ (raised bed seed cum fertilizer drill, $1092.83 \mathrm{~kg} / \mathrm{ha}$ ) where as it was found to be minimum for the treatment $\mathrm{T}_{2}$ (zero till seed cum fertilizer drill, $1008.5 \mathrm{~kg} / \mathrm{ha}$ ) followed by treatment $\mathrm{T}_{3}$ (conventional seed cum fertilizer drill, $1067.29 \mathrm{~kg} / \mathrm{ha}$ ). The findings of the present study envisage that for feeding the ever growing population and to earn higher returns, farmers should adopt the recommended management practices for rice-chickpea cropping system.

\section{Introduction}

Chickpea (Cicer arietinum L.) is an important winter season pulse crop of India and a key source of protein. In Chhattisgarh, chickpea is grown over an area of 393.78 thousand ha with an annual production of 433.15 thousand tones and an average productivity of 1100 $\mathrm{kg} / \mathrm{ha}$ (Anonymous, 2016-2017). It is an important winter season pulse crop of India with drought condition as single most important abiotic constraints of higher productivity (Kumar et al., 2006). Potential solutions to address these issues include a shift from intensive tillage based practices to conservation agriculture (CA) based crop management systems. Direct drilling (seeding/ planting with zero tillage technology) is one such practice that potentially addresses the issues of labor, energy, water, soil health etc. and adaptations to climatic variability (Jat et al., 2009). The major problem in wheat as well as chickpea sowing under no tillage is the frequent choking of the furrow opener of no-till drill due to long loose straw of paddy lying in the 
windrows, after harvesting by combines. However, the loose straw residue not burnt/spread on the ground resulted in frequent choking of drill in between furrow openers and frame of the drill. Keeping above points in view, farmer participatory trials were conducted to evaluate the performance of different farm machines for direct drilling of wheat in harvested paddy fields viz., happy seeder, national seed cum fertilizer drill, raised bed seed cum fertilizer drill and conventional seed drill in the research farm of IGKV, Raipur (C.G.) during 2017-18.

\section{Materials and Methods}

In this experiment, three different tillage treatments were studied. The details of tillage treatments are as follows: $F_{1}$ (Zero tillage), $F_{2}$ (Cultivator with two pass + Rotavator with two pass), $\mathrm{F}_{3}$ (Mould Board Plough with one pass + Cultivator with two pass + Rotavator with two passes). To evaluate the performance of happy seeder and to study on different sowing machines (Fig. 1) for chickpea cultivation, the following sowing machines were used in the experiment for sowing of chickpea; $S_{1}$ (Happy seeder); $S_{2}$
(Zero till seed cum fertilizer drill); $\mathrm{S}_{3}$ (Conventional seed cum fertilizer drill) and $\mathrm{S}_{4}$ (Raised bed seed cum fertilizer drill). The three number of replications were performed on field. In each replication, the sequence of all treatments was different. The following treatments were used in the experiment for sowing of chickpea: $\mathrm{T}_{1}-\left(\mathrm{F}_{1} \mathrm{~S}_{1}\right), \mathrm{T}_{2^{-}}\left(\mathrm{F}_{1} \mathrm{~S}_{2}\right)$, $\mathrm{T}_{3^{-}}\left(\mathrm{F}_{2} \mathrm{~S}_{3}\right)$ and $\mathrm{T}_{4^{-}}\left(\mathrm{F}_{3} \mathrm{~S}_{4}\right)$. Table 1 shows condition of land, crop and machinery related parameters.

\section{Results and Discussion}

The maximum number of branches/plant after 20, 40 and 80 days of sowing was counted in treatment T1 (happy seeder, 3.15, 8.45 and 15.92 , respectively) whereas it was found to be minimum for the treatment $\mathrm{T} 2$ (zero till seed cum fertilizer drill, 2.27, 7.78 and 14.43, respectively). There was more number of branches/plant in treatments T3 and T4 than treatment $\mathrm{T}_{2}$. The maximum number of pods per plant was counted in treatment T1 (72.2) followed by treatment T4 (69.3) where as it was found to be minimum for the treatment T2 (62.2) followed by treatment T3 (52.7).

Table.1 Land related parameters

\begin{tabular}{|c|l|r|}
\hline S. No. & Particulars & Specification \\
\hline 1. & Experimental field & IGKV research farm \\
\hline $\mathbf{2 .}$ & Number of treatment & 4 \\
\hline 3. & Number of tillage practices & 3 \\
\hline $\mathbf{4 .}$ & Number of sowing method & 4 \\
\hline $\mathbf{5 .}$ & Replications & 3 \\
\hline $\mathbf{6 .}$ & Field size & $0.4043 \mathrm{ha}$ \\
\hline $\mathbf{7 .}$ & Plot size & $30 \times 10 \mathrm{~m}$ \\
\hline $\mathbf{8 .}$ & Distance between replications & $1.0 \mathrm{~m}$ \\
\hline $\mathbf{9 .}$ & Distance between plots & $0.5 \mathrm{~m}$ \\
\hline $\mathbf{1 0 .}$ & Total number of plots & 12 \\
\hline $\mathbf{1 1 .}$ & Season of Experiment & Rabi \\
\hline $\mathbf{1 2 .}$ & Crop & Chickpea \\
\hline $\mathbf{1 3 .}$ & Variety & JG -130 \\
\hline $\mathbf{1 4}$ & Date of sowing & 9 Nov, 2017 \\
\hline
\end{tabular}


Table.2 Measurement of yield attributing characters

\begin{tabular}{|c|c|c|c|c|c|}
\hline S. No. & Treatments & Pods/plant & Grain Yield & Straw Yield & 100 Grain \\
kg/ha & & 1137.80 & 3674.50 & 28.43 \\
\hline 1. & $\mathrm{T}_{1}$ & 72.60 & 1008.50 & 3129.96 & 26.96 \\
\hline 2. & $\mathrm{T}_{2}$ & 62.20 & 1067.29 & 3314.54 & 27.20 \\
\hline 3. & $\mathrm{T}_{3}$ & 67.70 & 1092.89 & 3631.44 & 27.80 \\
\hline 4. & $\mathrm{T}_{4}$ & 69.30 & & & \\
\hline
\end{tabular}

Table.3 Measurement of crop parameters

\begin{tabular}{|c|c|c|c|c|c|c|c|c|c|c|c|c|c|c|c|}
\hline \multirow[t]{2}{*}{$\begin{array}{l}\text { S. } \\
\text { No. }\end{array}$} & \multirow[t]{2}{*}{$\begin{array}{l}\text { Treat } \\
\text { ments }\end{array}$} & \multirow[t]{2}{*}{$\begin{array}{l}\text { Depth of } \\
\text { Sowingcm }\end{array}$} & \multirow{2}{*}{$\begin{array}{c}\text { Seed } \\
\text { Emergence } \\
\%\end{array}$} & \multicolumn{3}{|c|}{ Plant Population $/ \mathrm{m}^{2}$} & \multicolumn{3}{|c|}{ Plant Height, cm } & \multicolumn{3}{|c|}{ Depth of Root, cm } & \multicolumn{3}{|c|}{$\begin{array}{c}\text { Number of } \\
\text { Branches/Plant }\end{array}$} \\
\hline & & & & $\begin{array}{c}20 \\
\text { DAS }\end{array}$ & $\begin{array}{c}40 \\
\text { DAS }\end{array}$ & $\begin{array}{c}80 \\
\text { DAS }\end{array}$ & $\begin{array}{c}20 \\
\text { DAS }\end{array}$ & $\begin{array}{c}40 \\
\text { DAS }\end{array}$ & $\begin{array}{c}80 \\
\text { DAS }\end{array}$ & $\begin{array}{c}20 \\
\text { DAS }\end{array}$ & $\begin{array}{c}40 \\
\text { DAS }\end{array}$ & $\begin{array}{c}80 \\
\text { DAS }\end{array}$ & $\begin{array}{c}20 \\
\text { DAS }\end{array}$ & $\begin{array}{c}40 \\
\text { DAS }\end{array}$ & $\begin{array}{c}80 \\
\text { DAS }\end{array}$ \\
\hline 1. & $\mathrm{~T}_{1}$ & 3.22 & 87.10 & 55.68 & 53.52 & 48.91 & 8.67 & 24.72 & 54.34 & 2.17 & 7.97 & 14.58 & 3.15 & 8.45 & 15.92 \\
\hline 2. & $\mathrm{~T}_{2}$ & 3.45 & 86.00 & 52.78 & 49.13 & 43.23 & 7.12 & 23.01 & 52.09 & 2.06 & 7.80 & 14.28 & 2.27 & 7.78 & 14.43 \\
\hline 3. & $\mathrm{~T}_{3}$ & 3.82 & 86.70 & 54.31 & 51.23 & 45.43 & 7.92 & 23.78 & 52.72 & 3.52 & 9.01 & 15.72 & 2.83 & 8.02 & 15.03 \\
\hline 4. & $\mathrm{~T}_{4}$ & 4.41 & 86.90 & 53.92 & 50.42 & 44.41 & 8.19 & 24.17 & 53.11 & 3.68 & 9.12 & 15.91 & 2.98 & 8.21 & 15.19 \\
\hline
\end{tabular}


Fig.1 Sowing of chickpea with happy seeder and other implements

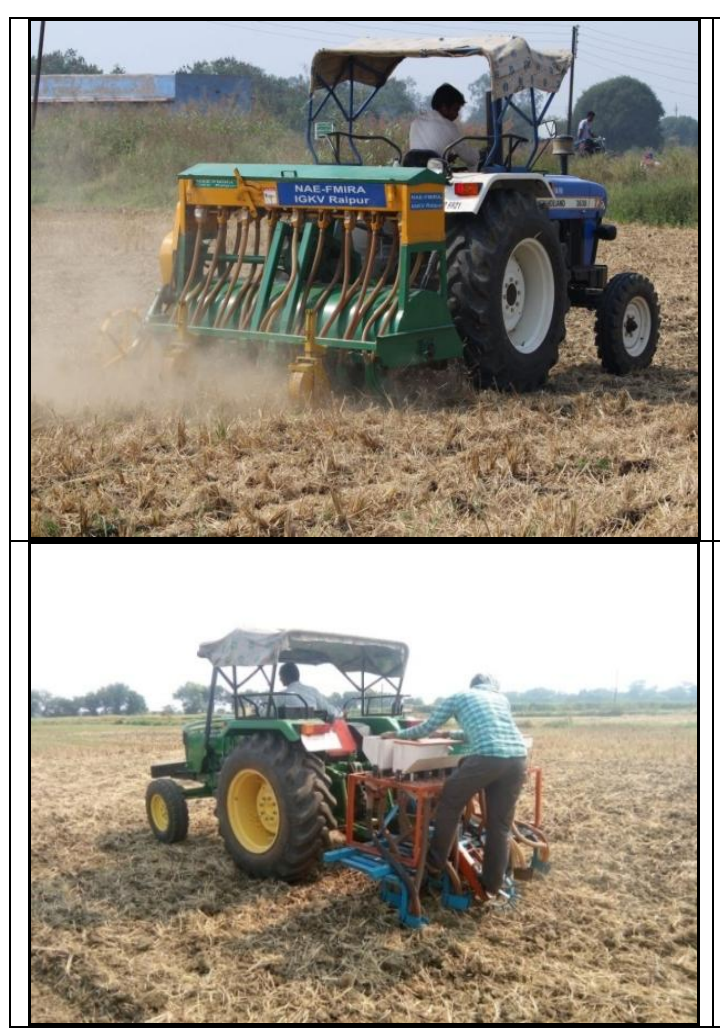

The maximum total yield of chickpea grain was obtained in treatment $\mathrm{T} 1(1137.8 \mathrm{~kg} / \mathrm{ha})$ followed by treatment T4 $(1092.83 \mathrm{~kg} / \mathrm{ha})$ where as it was found to be minimum for the treatment T2 (1008.5 kg/ha) followed by treatment T3 (1067.29 kg/ha). The maximum weight of 100 grain was obtained in treatment T1 (28.43 g) followed by treatment T4 (27.8 g) where as it was found to be minimum for the treatment T2 $(26.96 \mathrm{~g})$ followed by treatment T3 (27.2 g). The yield and crop parameters are shown in table 2 and 3 respectively

From the above data we have been concluded that the parameters pertaining to happy seeder shows maximum profits than other used machinery. Through this study we have also pointed out that at some places due to the jumping of ground wheel certain amount of seed cannot be placed at desired depth. But overall yield attributes show that the farmer

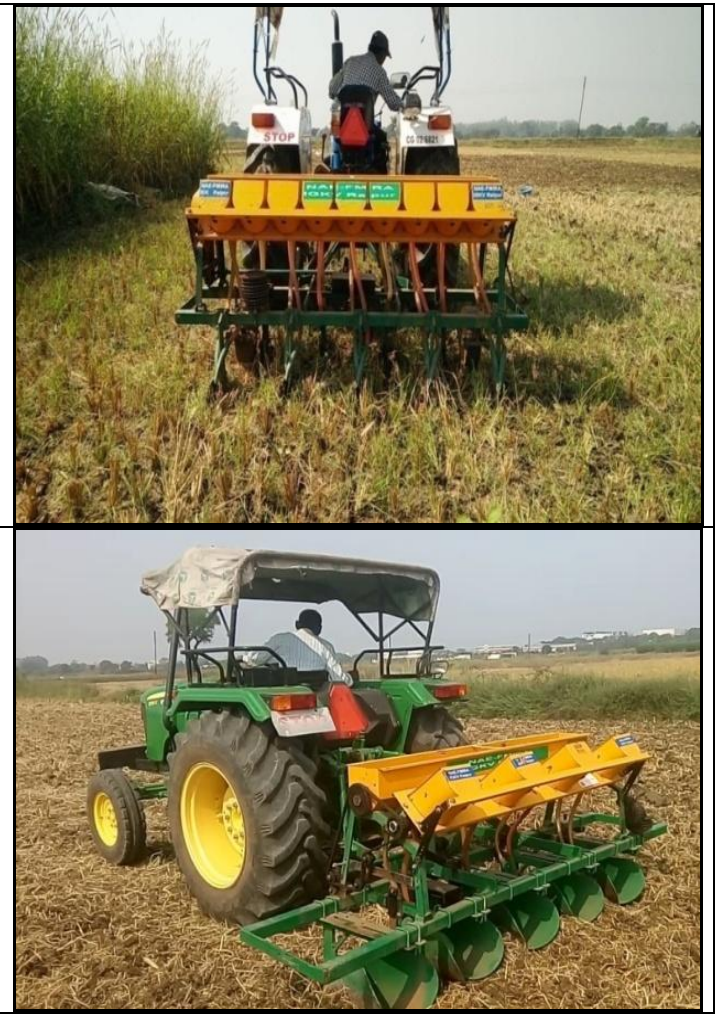

should adopt this technology for maximum productivity in rice-chickpea cropping system of Chhattisgarh.

\section{References}

Chauhan, A., Jha, G., Chourasiya, A., Jha, A., and Joshi, J. K. 2017. Effect of tillage and weed management practices and growth productivity and energy analysis of late -sown chickpea. International Journal of Agriculture Sciences., 9(5): 3779-3781.

Jat, M. L., Kamboj, B. R., Sidhu, H. S., Singh, M., Bana, A., Bishnoi, D. K., and Jat, H. S. (2013). Operational manual for Turbo Happy SeederTechnology for managing crop residues with environmental stewardship.

Kumar, R., Arya, R.L. and Mishra, J.P. 2006. Effect of seed priming and tillage 
management on productivity of chickpea genotype under rain fed conditions. Indian J. Agronomy, 51 (1): 54-56.

Sahay, K. M., and Singh, K. K. 1994. A Textbook of Unit Operation of Agricultural Processing. Vikas Publication House PVT LTD., pp. 103-161.
Singh, Y., and Singh, S. 2007. The happy seeder enables direct drilling of wheat into rice stubble. Aus. J. Exp., 4(7): 844-854.

Singh, A., Kang, J. S., and Kaur, M. 2013. Planting of wheat with happy seeder and rotavator in rice stubbles. IndoAm. J. Agric. and Vet. Sci., 1(8):372379.

Sidhu, H. S., Singh, M., Humphreys, E.,

\section{How to cite this article:}

Yogesh Ku. Kosariya, A.K. Verma, Shubham and Sangeeta. 2019. Effect of Different Types of Tillage and Sowing Methods on Growing and Yield of Chickpea Crop. Int.J.Curr.Microbiol.App.Sci. 8(02): 2623-2627. doi: https://doi.org/10.20546/ijcmas.2019.802.306 